\title{
A Tale Of Two Countries: What The United States Can Learn From Brazil About Reducing Dependence On Foreign Oil
}

\author{
Robert B. Matthews, Sam Houston State University, USA
} Eric Steglich, USA

\begin{abstract}
Dependence on foreign oil by the United States of America creates massive problems from the economic, environmental, and national security perspectives. In recognition of this reality, the USA embarked upon an energy independence plan in the mid-1970s, following the Arab oil embargo that accompanied the 1973 Yom Kippur War. Unfortunately, this effort has failed to the extent that the USA is more dependent upon foreign oil today than it was in 1976. At about the same time that the USA initiated its energy effort, a similar effort was also initiated in the South American nation of Brazil, which like the USA was alarmingly dependent upon foreign oil and had sustained substantial economic hardship as a result of the Arab embargo. Today, Brazil is substantially energy independent, and in fact exports oil to the USA. Obviously, Brazil implemented a more effective energy independence effort than did the USA. Lessons which the author believes may be learned from the Brazilian experience are that solving the problem requires that all possible solutions be pursued simultaneously with maximum vigor, that maximum use should be made of existing usable technology rather than waiting for laboratory-scale technologies to be perfected, and that solutions will be reached much faster if the private sector is actively engaged in a cooperative rather than adversarial manner. With these principles in mind, we review available alternatives and propose a comprehensive energy strategy that reduces the USA's dependence on foreign oil in the short run, and ultimately eliminates that dependence in the long run. We further enunciate reasons for believing that such an integrated strategy is far superior to any effort to address the problem by focusing solely upon conservation, or alternative fuels, or "drill here, drill now," to the exclusion or minimization of the other approaches. We conclude with a proposed plan for implementing the "all hands on deck" approach to energy independence.
\end{abstract}

Keywords: Energy; oil; natural gas; ethanol; nuclear; alternative energy; conservation

\section{INTRODUCTION}

e can do limited offshore drilling with strict environmental oversight, while creating tax incentives
to get Detroit making hybrid and electric cars. That way, the offshore drilling carries us until the
new technologies kick in, which will then create new jobs and energy independence. Energy crisis solved. --Paris Hilton

In the wake of the Arab oil embargo that accompanied the 1973 Yom Kippur War, many developed and developing countries experienced severe oil supply shortages, with significant consequent damage to their economies and their overall well being. In the United States of America, consumers experienced gasoline shortages, rapidly increasing gasoline prices, gasoline lines, odd-even gasoline rationing, and a number of other adverse impacts. The experience, and a repeat in 1979 following the fall of the government of the Shah of Iran, galvanized public opinion in favor of the goal of becoming independent of foreign sources of oil and natural gas. President Jimmy Carter announced the goal of energy independence, and a plan to achieve that goal, and every administration 
since Carter's has at least paid lip service to the goal of energy independence. In the years since, environmental and national security objectives have joined the economic objective for ending dependence on foreign oil, but despite the urgency there has been relatively little progress toward the objective. The U.S. imports more oil today than did in the Carter years, and reasonable forecasts agree that such dependence will become greater in at least the short run. The events of the 1970s impacted Brazil even more than they did the U.S. At the time, oil imports accounted for $90 \%$ of Brazil's oil consumption (Reel, 2006), and $40 \%$ of its total foreign trade account deficit. Today, Brazil is one of the ten largest suppliers of oil to the United States. This paper compares Brazil's energy efforts to those of the U.S., and develops a recommended approach for the U.S. that takes advantage of the lessons learned by Brazil.

Looking first at the U.S., Brookings Institute Fellow David Sandalow has written that the "United States is in a long war," and that dependence on foreign oil threatens national security, the environment, and the economy (Sandalow, 2007, p.4). The importance of each of those elements is clear.

- National Security. The cost to protect our overseas oil infrastructure is great. Oil dependence is an important cause of terrorist attacks on the United States. There are reasons to believe that a significant portion of the enormous transfer of funds for foreign oil is funneled into terrorist groups in the Middle East.

- $\quad$ Environment. Oil and other fossil fuels emit polluting agents into our atmosphere. Recent increases in global temperatures have been widely attributable to man-made greenhouse gases. Even those who question the global warming impact cannot deny that there are other harmful environmental aspects of fossil-fuel pollution.

- $\quad$ Economy. Excessive dependence on oil can have a drastic affect on the economy because of the volatility of oil markets. "Price increases can occur suddenly and, because there are no widely available substitutes for oil, consumers and businesses may be unable to respond by changing consumption patterns (Sandalow, 2007, p. 6)." Additionally at current levels and at a price of $\$ 100$ per barrel, oil imports contribute almost $\$ 450$ billion per year to the US trade deficit.

Bordetsky, Hwang, Korin, Lovaas, and Tonachel, in a paper prepared for the Natural Resources Defense Council, stated that oil "dependence has become the Achilles heel of America's economy and national security" (Bordetsky, et al, 2005, p. 11). Clearly this is an issue that demands a solution. Unfortunately, in the years since declaring the goal of energy independence in the 1970s, the USA has become more, not less, dependent on foreign oil; the US imports roughly 12 million barrels of oil per day now, compared to 6 million in 1973-75 (DOE, 2011).

One problem with the discussion of energy policy is the failure of many proposed approaches to achieve sufficient volumes to impact overall energy use materially. Therefore it is helpful to review the current sources and uses of energy in the USA, as summarized in the following table:

Table 1

\begin{tabular}{|c|c|c|c|c|c|c|}
\hline \multirow{2}{*}{$\begin{array}{l}\text { (Amounts in quadrillions } \\
\text { of British Thermal Units } \\
\text { [BTU], per DOE/EIA, } \\
\text { with interpolation } \\
\text { by the author) }\end{array}$} & \multirow[b]{2}{*}{$\begin{array}{c}\text { Produced } \\
\text { or purchased }\end{array}$} & \multicolumn{5}{|c|}{ Used For } \\
\hline & & Transport & Industrial & Commercial & Residential & Electricity \\
\hline \multicolumn{7}{|l|}{ Oil } \\
\hline -Domestic & 14.0 & & & & & \\
\hline -Imported & 26.0 & & & & & \\
\hline Total & 40.0 & 27.8 & 9.4 & 0.8 & 1.1 & 0.9 \\
\hline Natural gas & 23.6 & 0.7 & 7.9 & 3.8 & 4.1 & 7.1 \\
\hline Coal & 22.8 & & 1.9 & 0.1 & 0.1 & 20.7 \\
\hline Renewables & 6.8 & 0.6 & 2.0 & 0.3 & 0.4 & 3.5 \\
\hline Nuclear & 8.4 & & & & & 8.4 \\
\hline Subtotals & 101.6 & 29.1 & 21.2 & 5.0 & 5.7 & 40.6 \\
\hline Use of electricity & & & 11.1 & 13.4 & 16.1 & $(40.6)$ \\
\hline Totals & 101.6 & 29.1 & 32.3 & 18.4 & 21.8 & - \\
\hline
\end{tabular}


A barrel of oil represents $5800 \mathrm{BTU}$, so 40 quadrillion BTU from oil converts to approximately 19 million barrels per day. The Department of Energy's latest forecast shows this number growing to about 21.9 million barrels per day in 2035 (DOE/EIA, 2011, Outlook). With respect to the oil portion of the above, US oil production and consumption, in millions of barrels per day, are as follows for recent years and the near future (DOE/EIA, 2011, Table 4a and Table of US Oil Imports):

Table 2

\begin{tabular}{|l|c|c|c|c|c|}
\hline & \multicolumn{3}{|c|}{ Historic } & \multicolumn{2}{c|}{ Projected } \\
\hline & $\mathbf{2 0 0 8}$ & $\mathbf{2 0 0 9}$ & $\mathbf{2 0 1 0}$ & $\mathbf{2 0 1 1}$ & $\mathbf{2 0 1 2}$ \\
\hline Domestic production & & & & & \\
\hline - Crude oil & 4.95 & 5.36 & 5.51 & 5.40 & 5.27 \\
\hline - Natural gas liquids & 1.78 & 1.91 & 2.00 & 2.03 & 2.01 \\
\hline Total Domestic Production & 6.73 & 7.27 & 7.51 & 7.43 & 7.28 \\
\hline Imports & & & & & \\
\hline - Crude oil & 9.78 & 9.01 & 9.16 & 9.29 & 9.56 \\
\hline - Refined products & 3.13 & 2.68 & 2.59 & 2.37 & 2.48 \\
\hline Total Imports & 12.91 & 11.69 & 11.75 & 11.66 & 12.04 \\
\hline Total Oil/Liquids & 19.64 & 18.96 & 19.26 & 19.09 & 19.32 \\
\hline Ethanol and other renewables & 0.65 & 0.76 & 0.92 & 0.95 & 0.96 \\
\hline Refinery gains & 1.01 & 1.03 & 1.28 & 1.25 & 1.25 \\
\hline Total Supply & 21.30 & 20.79 & 21.46 & 21.29 & 21.53 \\
\hline
\end{tabular}

Refinery gains occur because the refining process is essentially a physical process of separating various components from the crude oil stream rather than a chemical process, and the combined volume of components when segregated typically exceeds the volume of the entire stream in which they were commingled. It should also be noted that President Barack Obama announced in a press conference on March 11, 2011, that for the year 2010 the USA had produced more oil domestically than it imported (Obama, 2011). This can be reconciled with the above data if we include crude oil, natural gas liquids, ethanol, and refinery gains in the domestic production volume, and exclude refined products from the imported volume. That is arguably not the most intuitive or straightforward way to interpret the data.

Approximately $3 / 4$ of US petroleum imports come from the following 10 countries (Source: DOE/EIA, 2011, US Imports by Country of Origin):

Table 3

\begin{tabular}{|c|c|c|c|c|c|c|c|c|}
\hline \multirow{3}{*}{ Country } & \multicolumn{2}{|c|}{ Member of } & \multirow{2}{*}{\multicolumn{5}{|c|}{$\begin{array}{l}\text { Daily Average Imports } \\
\text { (thousands of BBL/day) }\end{array}$}} & \multirow{2}{*}{$\begin{array}{c}\text { Percent of Total US } \\
\text { Imports, 2010 } \\
\end{array}$} \\
\hline & OPFC & HATA & & & & & & \\
\hline & UPEC & NAF IA & 1995 & 2000 & 2005 & 2009 & 2010 & \\
\hline \multicolumn{9}{|l|}{ Americas } \\
\hline Canada & & $\mathrm{X}$ & 1,332 & 1,807 & 2,181 & 2,479 & 2,532 & $22 \%$ \\
\hline Mexico & & $\mathrm{X}$ & 1,068 & 1,373 & 1,662 & 1,210 & 1,280 & $11 \%$ \\
\hline Venezuela & $\mathrm{X}$ & & 1,480 & 1,546 & 1,529 & 1,063 & 987 & $9 \%$ \\
\hline Brazil & & & 8 & 51 & 156 & 309 & 271 & $2 \%$ \\
\hline \multicolumn{9}{|l|}{ Persian/Arabian Gulf } \\
\hline Saudi Arabia & $\mathrm{X}$ & & 1,344 & 1,572 & 1,537 & 1,004 & 1,094 & $9 \%$ \\
\hline Iraq & $\mathrm{X}$ & & 0 & 620 & 531 & 450 & 414 & $4 \%$ \\
\hline \multicolumn{9}{|l|}{ Africa } \\
\hline Nigeria & $\mathrm{X}$ & & 627 & 896 & 1,166 & 809 & 1,025 & $9 \%$ \\
\hline Algeria & $\mathrm{X}$ & & 234 & 225 & 478 & 493 & 507 & $4 \%$ \\
\hline Angola & $\mathrm{X}$ & & 367 & 301 & 473 & 460 & 390 & $3 \%$ \\
\hline \multicolumn{9}{|l|}{ Other } \\
\hline Russia & & & 25 & 72 & 410 & 563 & 611 & $5 \%$ \\
\hline Totals For Countries Listed & & & 6,485 & 8,463 & 10,123 & 8,940 & 9,211 & $78 \%$ \\
\hline Other Countries & & & 2,450 & 2,996 & 3,591 & 2,750 & 2,542 & $22 \%$ \\
\hline Total US Imports & & & 8,835 & 11,459 & 13,714 & 11,690 & 11,753 & $100 \%$ \\
\hline
\end{tabular}


Note that the majority of US oil imports do not come from the Persian/Arabian Gulf area. Most of the oil produced in that region actually goes to Western Europe, India, China, and Japan, making the extent of US military involvement in the area, and the relative lack of military involvement by the countries more directly affected, somewhat troubling. The problem is that oil is a nearly fungible commodity, and if supplies from the Gulf were cut off, the countries relying on oil from there would have no alternative but to compete with us for oil from places like Nigeria, Algeria, Angola, and Russia, and that would drive the worldwide price astronomically upward, harming our economy as much as those of the actual users of that oil. Of course, opponents may argue that our involvement is more about empire than oil, or that we should not be spending more to secure energy supplies for Europe and Japan than Europe are spending to secure those supplies, and those arguments are not devoid of merit.

The largest suppliers of oil to the US are our nearest neighbors and NAFTA partners - Canada and Mexico. That is logical, given the cost of transporting oil. Including the Alberta tar sands, Canada's recoverable reserves of oil to be produced in the future are second only to Saudi Arabia, as indicated by the following (average of BP Statistical Review, Oil and Gas Journal, and World Oil estimates, per DOE/EIA, 2009):

Table 4

\begin{tabular}{|c|c|c|}
\hline Country & $\begin{array}{c}\text { Included in } 10 \text { Largest Suppliers } \\
\text { of Imported Oil to USA }\end{array}$ & $\begin{array}{c}\text { Recoverable Reserves } \\
\text { (billions of barrels) }\end{array}$ \\
\hline Saudi Arabia & $\mathrm{X}$ & 265,000 \\
\hline $\begin{array}{l}\text { Canada } \\
\text { (conventional 27,000, tar sands } 151,000 \text { ) }\end{array}$ & $\mathrm{X}$ & 178,000 \\
\hline Iran & & 137,000 \\
\hline Iraq & $\mathrm{X}$ & 122,000 \\
\hline Kuwait & & 101,000 \\
\hline Venezuela & $\mathrm{X}$ & 89,000 \\
\hline United Arab Emirates & & 88,000 \\
\hline Russia & $\mathrm{X}$ & 72,000 \\
\hline Libya & & 40,000 \\
\hline Nigeria & $\mathrm{X}$ & 37,000 \\
\hline Kazakhstan & & 35,000 \\
\hline United States & Domestic & 24,000 \\
\hline Qatar & & 21,000 \\
\hline China & & 16,000 \\
\hline Brazil & $\mathrm{X}$ & 13,000 \\
\hline Algeria & $\mathrm{X}$ & 12,000 \\
\hline Mexico & $\mathrm{X}$ & 11,000 \\
\hline Angola & $\mathrm{X}$ & 9,000 \\
\hline Norway & & 7,000 \\
\hline Azerbaijan & & 7,000 \\
\hline Oman & & 6,000 \\
\hline Total Listed & & $1,290,000$ \\
\hline Other countries & & 60,000 \\
\hline Total World & & $1,350,000$ \\
\hline
\end{tabular}

Note that all ten of the largest suppliers of imported oil to the USA are included in the above listing, although the future recoverable reserves for Brazil, Algeria, Mexico, and Angola are on the low end of those listed. Brazil, in particular, has an ambitious ongoing program of oil and gas development which has made, and can be expected to continue making, significant additions to its recoverable reserves. World oil consumption in barrels per day has grown as follows in recent decades (DOE/EIA, 2011, International Petroleum Consumption): 
Table 5

\begin{tabular}{|c|c|c|}
\hline Year & Consumption (barrels per day) & Percent increase over decade \\
\hline 1980 & $60,000,000$ & $6.7 \%$ \\
\hline 1990 & $64,000,000$ & $20.3 \%$ \\
\hline 2000 & $77,000,000$ & $9.0 \%$ \\
\hline
\end{tabular}

Note that the USA produces about $11 \%$ and consumes about $25 \%$ of world demand. Recent increases are attributable largely to growing economies in China, India, and other developing countries. At the current rate of worldwide oil consumption, the above worldwide oil reserves equate to about 44 years of production. Of course, total proved reserves includes both developed and undeveloped reserves, and a substantial portion of the total proved reserves have yet to be developed and produced. Such development and production will require considerable expenditures. For economic reasons, therefore, we have tended generally to have somewhere in the range of 10-15 years of developed and producing reserves at any time. Of course, we cannot accurately determine the amount of reserves present until they are developed and produced, but these estimates are developed using reasonable methodologies. What must be understood is that this does not mean we have 10 or 15 or 44 years before the oil runs out. The "peak oil" question must be addressed when new discoveries start to run out, but that has not been the case yet. However, at some point the question of how long we can continue to rely on oil must be faced. Given that the 44 years of reserves identified above represent what has been found with technology to date, and that finding new reserves is becoming technologically more difficult and substantially more expensive, it is not unreasonable to infer from the above that the era of relatively cheap oil will be over within something approaching 50 years, and therefore we need to be migrating away from oil in earnest by that time.

The problem with migrating away from oil is that it has proved to be very difficult to find a reasonable alternative to oil. Sandalow has identified ten key facts about oil, each with an important implication, as follows (Sandalow, 2008):

Table 6

\begin{tabular}{|l|l|}
\hline \multicolumn{1}{|c|}{ Fact } & \multicolumn{1}{|c|}{ Implication } \\
\hline $\begin{array}{l}\text { 1. Oil provides more than 96\% of the fuel for the } \\
\text { USA transportation fleet. }\end{array}$ & $\begin{array}{l}\text { The lack of substitutes is central to several of the most serious problems } \\
\text { caused by oil dependence. }\end{array}$ \\
\hline $\begin{array}{l}\text { 2. Oil provides less than 3\% of the electricity in } \\
\text { the USA. }\end{array}$ & $\begin{array}{l}\text { Technologies for generating electricity-such as nuclear, wind, and solar- } \\
\text { can't do much to help wean the USA from oil without major changes to our } \\
\text { transportation fleet. }\end{array}$ \\
\hline $\begin{array}{l}\text { 3. The USA consumes roughly a quarter of } \\
\text { world oil production. }\end{array}$ & $\begin{array}{l}\text { The USA is to oil consumption what Saudi Arabia is to oil production-the } \\
\text { largest, by far. }\end{array}$ \\
\hline $\begin{array}{l}\text { 4. The Persian/Arabian Gulf has the most oil in } \\
\text { the world-and the cheapest. }\end{array}$ & The USA has absolutely no competitive advantage in the production of oil. \\
\hline 5. Oil is a fungible product, traded globally. & A disruption in oil supplies anywhere will affect oil prices everywhere. \\
\hline $\begin{array}{l}\text { 6. Oil is the USA's largest source of heat- } \\
\text { trapping gases. }\end{array}$ & $\begin{array}{l}\text { Each year we remove millions of tons of carbon from underground oil } \\
\text { reserves and convert them into the heat-trapping gas, carbon dioxide. }\end{array}$ \\
\hline $\begin{array}{l}\text { 7. Roughly 69\% of our oil is used in the } \\
\text { transportation sector. }\end{array}$ & Demand for motor fuels dominates demand for crude oil. \\
\hline $\begin{array}{l}\text { 8. New car sales account for less than 7\% of the } \\
\text { total USA auto fleet every year. }\end{array}$ & $\begin{array}{l}\text { Reducing oil consumption through measures like CAFE standards will take } \\
\text { many years. }\end{array}$ \\
\hline $\begin{array}{l}\text { 9. The average household spends several } \\
\text { thousand dollars per year on gasoline. }\end{array}$ & Oil dependence exposes all Americans to the volatility of world oil markets. \\
\hline $\begin{array}{l}\text { 10. Huge majorities of Americans believe that } \\
\text { oil dependence is a serious problem. }\end{array}$ & $\begin{array}{l}\text { It is reasonable to expect support for a political leader who takes serious } \\
\text { steps to address it. }\end{array}$ \\
\hline
\end{tabular}

One reason that oil is so hard to replace is that it is a relatively efficient energy source. Cleveland, Costanza, Hall, and Kaufmann compared the "energy profit ratio" of various renewable and nonrenewable energy sources (Cleveland, et al, 1984), and Howard T. Odum compared the "energy yield ratio" (Odum, 1976). Their 
findings were summarized by Richard Heinberg (Heinberg, 2006, pp 162-164). Oil has yield rates in the range of 8 to 11 and natural gas in the range of 7 to 10 , with coal even higher. Among alternatives, only sugar cane ethanol (8.3 to 10.2, per Goettemoeller, 2007), 100-year growth rainforest (12.0 per Odum), hydroelectric (11.2 per Cleveland and 10.0 per Odum), solar photovoltaics (1.7 to 10.0, per Cleveland), geothermal from hot dry rock (1.9 to 13.0 per Cleveland and 13.0 per Odum), and tidal electric with a 25 -foot tide range ( 15.0 per Odum). The fossil fuels (oil, natural gas, coal) as a group produce significantly higher energy profit ratios or energy yield ratios than do most green alternatives. This differential is typically reflected in price; we depend so heavily on oil, and to a lesser extent on other fossil fuels, because they provide more energy cheaper than do the currently available alternatives.

One barrier to alternative energy sources is that the cost of those alternatives is higher than the cost of oil. However, the cost of oil is also rising. As time passes, we are still making significant discoveries (such as Brazil's finds in the Campos, Santos, and Espirito Santo basins) and as prices rise so will oil supplies, as some known reservoirs are economically viable to produce only at higher prices. But we appear to have found most of the "easy" oil, and what is discovered in the future can reasonably be expected to be more expensive to produce. Green, Jones, and Leiby, in a 1995 report prepared for the Office of Transportation Technology of the United States Department of Energy, forecasted that "in the long run the net price of oil (price minus marginal extraction costs) will rise steadily at the rate of interest" (Green, et al, 1995, p. 5). Since that time, oil prices have fluctuated wildly but the overall trend is clearly upward.

The Energy Information Administration of the U.S. Department of Energy (DOE/EIA) prepares an annual energy report and forecast with projections of future energy supply and demand, specifically projecting supply and demand components for 2020 and 2030. The 2007 and 2009 forecasts (DOE/EIA, 2007 and DOE/EIA, 2009) can be compared as follows (reference case, volumes in quadrillion Btu/year):

Table 7

\begin{tabular}{|c|c|c|c|c|c|c|c|c|c|}
\hline \multirow[b]{2}{*}{ Descriptions } & \multicolumn{2}{|c|}{ Current Data } & \multicolumn{2}{|c|}{2015 Projections } & \multicolumn{2}{|c|}{2020 Projections } & \multicolumn{2}{|c|}{2030 Projections } & \multirow{2}{*}{$\begin{array}{c}\text { Annual } \\
\text { Percent } \\
\text { Growth } \\
\text { 2007-2030 } \\
(2009 \\
\text { Report) }\end{array}$} \\
\hline & 2006 & 2007 & $\begin{array}{c}2007 \\
\text { Report }\end{array}$ & $\begin{array}{c}2009 \\
\text { Report }\end{array}$ & $\begin{array}{c}2007 \\
\text { Report }\end{array}$ & $\begin{array}{c}2009 \\
\text { Report }\end{array}$ & $\begin{array}{c}2007 \\
\text { Report }\end{array}$ & $\begin{array}{c}2009 \\
\text { Report }\end{array}$ & \\
\hline \multicolumn{10}{|l|}{ Domestic Production } \\
\hline -Oil & 10.8 & 10.7 & 11.6 & 12.4 & 14.9 & 14.1 & 13.7 & 16.0 & $1.7 \%$ \\
\hline -Natural gas & 19.0 & 19.9 & 21.2 & 20.9 & 21.4 & 22.1 & 21.2 & 24.3 & $0.9 \%$ \\
\hline -Plant liquids & 2.4 & 2.4 & 2.3 & 2.6 & & 2.6 & & 2.6 & $0.3 \%$ \\
\hline -Coal & 23.8 & 23.5 & 22.7 & 24.5 & 26.6 & 24.4 & 33.5 & 26.9 & $0.6 \%$ \\
\hline -Nuclear & 8.2 & 8.4 & 8.4 & 8.7 & 9.2 & 9.0 & 9.3 & 9.5 & $0.5 \%$ \\
\hline -Hydropower & 2.9 & 2.5 & 2.6 & 2.9 & 3.1 & 2.9 & 3.1 & 3.0 & $0.8 \%$ \\
\hline -Biomass & 3.0 & 3.2 & 3.7 & 5.2 & 4.7 & 6.5 & 5.3 & 8.2 & $4.2 \%$ \\
\hline -Other renew & 0.9 & 1.0 & 1.5 & 1.6 & 1.3 & 1.7 & 1.4 & 2.2 & $3.6 \%$ \\
\hline -Other & 0.3 & 0.9 & 0.6 & 1.0 & 0.9 & 1.1 & 1.1 & 1.1 & $0.9 \%$ \\
\hline Production & 71.3 & 72.5 & 74.6 & 79.8 & 82.1 & 84.4 & 88.6 & 93.8 & $1.1 \%$ \\
\hline \multicolumn{10}{|l|}{ Imports (Exports), net } \\
\hline- Oil & 26.7 & 26.0 & 21.6 & 20.8 & 28.9 & 19.0 & 34.7 & 18.6 & $-1.5 \%$ \\
\hline -Natural gas & 3.0 & 3.9 & 2.8 & 2.4 & 5.5 & 2.0 & 5.6 & 0.7 & $-2.6 \%$ \\
\hline -Coal & -1.3 & -1.5 & -1.8 & -1.7 & 0.4 & -1.3 & & -1.1 & $-1.4 \%$ \\
\hline -Other, net & 0.3 & 1.0 & 0.8 & 1.6 & 1.3 & 1.3 & 1.3 & 1.5 & $1.3 \%$ \\
\hline Production Plus Imports & 100.0 & 101.9 & 98.0 & 102.9 & 118.2 & 105.4 & 131.2 & 113.5 & $0.5 \%$ \\
\hline \multicolumn{10}{|l|}{ Consumption } \\
\hline -Residential & 20.8 & 21.8 & 21.9 & 21.9 & & 22.7 & & 24.0 & $0.4 \%$ \\
\hline -Commercial & 17.8 & 18.5 & 18.5 & 20.1 & & 21.5 & & 23.6 & $1.1 \%$ \\
\hline -Industrial & 32.8 & 32.7 & 30.1 & 32.2 & & 32.2 & & 33.9 & $0.1 \%$ \\
\hline -Transport & 28.6 & 28.9 & 27.5 & 28.7 & & 29.0 & & 32.0 & $0.5 \%$ \\
\hline Consumption & 100.0 & 101.9 & 98.0 & 102.9 & & 105.4 & & 113.5 & $0.5 \%$ \\
\hline
\end{tabular}


The 2009 forecast differs from the 2007 forecast primarily in that it considers the impact of the decline in energy consumption during the latter half of 2008. Although both forecasts predict an increase in domestic oil and gas production as well as energy from other source, both forecasts leave the U.S. very much dependent on foreign oil as far into the future as 2030 .

President Barack Obama has stated, "And for the sake of our economy, our security, and the future of our planet, I will set a clear goal as president: In 10 years, we will finally end our dependence on oil from the Middle East (Obama, 8/28/2008)." Unfortunately, it does not appear that the energy program outline by President Obama will accomplish that goal. Efforts to develop wind, solar, and improved insulation for buildings will have minimal impacts on oil usage. Perhaps the signature element - the electric automobile - is now coming into use, with a goal of 1 million on the road by 2015 (Obama, 1/25/2011). Assuming that each electric vehicle saves 4 gallons of gasoline per day, achieving that goal would reduce current oil consumption by about 200,000 barrels per day, or less than 1 percent. It is entirely likely that on the current path, the US will import more oil in 2015 than today, thus continuing the trend of the last 40 years of becoming ever more dependent on foreign oil.

To date, the US has fallen far short of its intended goal of reducing its dependency on foreign oil. In fact that dependency has increased rather than decreased. It is the opinion of the authors that this results from three flaws in the US approach:

- $\quad$ There has been a focus on developing a perfect solution in a laboratory environment and then implementing it, rather than making use of what is available.

- $\quad$ Particularly with respect to oil, the perfect alternative has not been found, nor at this point is there any strong suggestion of what it might be.

- $\quad$ Regulations have hampered many private sector efforts to develop solutions.

As a result the US finds itself in a position where it must address two potentially negative factors:

- $\quad$ The era of cheap energy is coming to an end.

- $\quad$ We currently have no good substitutes for oil.

\section{THE APPROACH TAKEN BY BRAZIL}

Brazil, which was even more dependent on foreign oil than was the U.S. in the 1970s, is today virtually energy-independent. Because of transportation considerations and difficulties refining heavy oil, Brazil does import some oil, primarily from Bolivia (although that is expected to change once production in the offshore Campos, Santos, and Espirito Santo basins is up to speed), but it exports sufficient oil to be a net exporter of energy. Brazil is now among the ten largest suppliers of oil to the USA.

Clearly, the Brazilian economy in general, and its energy consumption in particular, is significantly smaller than in the USA, so some lessons are not strictly applicable. However, Brazil clearly did some things better than the U.S., and there are some broad general principles that have significant applicability.

Brazil's well-known and massive effort to develop alternatives to gasoline (sugar cane ethanol) and diesel fuel (soybean-based biodiesel) has replaced approximately 50\% of gasoline and $44 \%$ of the country's on-the-road motor fuel. It should be noted that criticism that Brazil has destroyed the Amazon basin to produce ethanol is unfounded. Sugar cane is produced in the Brazilian states of Mato Grosso, Mato Grosso do Sul, Goias, Minas Gerais, Sao Paulo, Parana, Rio de Janeiro, Espirito Santo, Rio Grande do Norte, Paraiba, Pernambuco, Alagoas, and Sergipe. The area with maximum potential for expansion lies in the states of Mato Grosso, Mato Grosso do Sul, and Goias. All these areas lie outside the Amazon basin (Lachlau, Sergio Andre, in Schwind, 2007). Further, it is estimated that approximately $65 \%$ of the area now producing sugar cane was converted from pasture land before. Brazil does also produce a significant amount of biodiesel, primarily from soybeans, and a considerable amount of soybean production does take place in areas that have been cleared in the Amazon basin. 
What may be less well known is that Brazil's approach also included significant amounts of increased domestic exploration for oil and gas (the source of the other $56 \%$ of motor fuel) and hydroelectric (35\% of Brazil's total energy needs). Today Petrobras is perhaps the world's leading center of expertise in deep water drilling. This has resulted in significant new finds in the offshore Santos, Campos and Espirito Santo basins. While Brazil's recoverable reserves of oil and gas are less than those of the U.S., they are growing rapidly, and continued development could transform Brazil into one of the largest oil producers in the world (DOE/EIA, Brazil country brief, 2011).

This emphasis on a broad frontal attack on the problem from all sources was accompanied by a strong bias in favor of action, specifically action utilizing known technology rather than waiting for future technologies to prove themselves. The ethanol plants are themselves relatively primitive, particularly when compared to a U.S. oil refinery (Schwind, 2007). Brazil has refused to become slave to "perfect" or to allow "perfect" to become the worst enemy of "good enough." This is quite a contrast to the U.S. effort, where there has been considerable research into a "perfect" solution, but comparatively little effort to get "good enough" solutions implemented.

Brazil's approach also included a heavy orientation toward the private sector and free markets. Realizing that as a government-owned entity, Petrobras would likely be too bureaucratic and not sufficiently nimble to respond as needed, the government sold a large stake in the company and passed management duties and privileges to the non-government shareholders. Brazil moved further toward a free-market approach by ending Petrobras's exclusive concession to develop all domestic oil and gas, and invited foreign companies to come in and take down exploration and production concessions. The mechanisms whereby sugar growers determine whether to sell there produce for making into sugar or into ethanol, and similarly the mechanisms whereby motorists decide whether to burn gasoline or ethanol in their autos (which are set up to burn either) rely almost entirely upon free-market principles. The sugar cane grower compares the prices he can receive at the sugar mill and at the ethanol plant before deciding where to sell his crop. Because automobiles and trucks are configured to run on either gasoline/diesel or ethanol/bio-diesel, the motorist can check the price of each, adjust for performance differential, and make a rational economic decision which one she should put into her vehicle today. Using sugar cane ethanol as the "swing" product introduces some price elasticity to both sugar and oil. While the sugar market is depressed today, lower sugar prices mean that farmers will deliver more sugar cane to the ethanol plant, and ethanol prices give some insulation against oil—and resulting gasoline-price shocks.

The lessons to be learned from the Brazilian experience may be summarized as follows:

Table 8

\begin{tabular}{|l|l|}
\hline \multicolumn{1}{|c|}{ United States Of America } & \multicolumn{1}{|c|}{ Brazil } \\
\hline $\begin{array}{l}\text { The U.S. has debated the question of "drill here, drill } \\
\text { now" versus alternatives versus conservation. The } \\
\text { emphasis has been on debate and discussion rather than } \\
\text { action. }\end{array}$ & $\begin{array}{l}\text { Brazil pursued all available options vigorously and simultaneously. } \\
\text { The Brazilian approach has been "drill here, drill now" plus } \\
\text { alternatives plus conservation. There has been a strong bias toward } \\
\text { action. }\end{array}$ \\
\hline $\begin{array}{l}\text { The U.S. has focused upon developing the "perfect" } \\
\text { solution in the laboratory and then bringing that solution } \\
\text { to reality. }\end{array}$ & $\begin{array}{l}\text { Brazil utilized existing technology to the maximum extent possible, } \\
\text { and phased in improved technologies as they make the transition } \\
\text { from laboratory to real world usefulness. Brazil has vigorously } \\
\text { avoided letting "perfect" get in the way of "good enough". }\end{array}$ \\
\hline $\begin{array}{l}\text { The U.S. government has maintained an adversarial } \\
\text { stance toward the energy industry, and has sought to } \\
\text { regulate its activities heavily. }\end{array}$ & $\begin{array}{l}\text { Brazil has pushed toward a more cooperative approach with the } \\
\text { energy industry, and generally allowed the free market to work. }\end{array}$ \\
\hline
\end{tabular}

\section{APPLYING THE LESSONS FROM BRAZIL TO THE UNITED STATES}

These lessons learned from Brazil can be applied to address the USA's energy problems. Conservation, alternatives, and increased production from conventional domestic sources must be accompanied by vigorous research and development effort. Rather than wait for perfect technology to be developed, the timing is such that we need to implement some "good enough" steps today. Participation by the private sector in an energy market that sends the right price signals is the fastest way to make real progress; this requires a more cooperative, rather than 
adversarial, relationship with government, and efforts to ensure that free markets send the proper economic signals. The good news is that a solution appears possible. The bad news is that it will not be cheap. The era of cheap energy is over.

\section{Pursuing All Available Options}

Pursuing all available options means that conservation, alternative fuels, and increased production of domestic fuel_-fossil and non-fossil—must be accomplished vigorously and simultaneously.

\section{Conservation}

The potential to "find" energy by saving it through conservation is enormous. The USA currently consumes 68.672 barrels of oil per day per 1,000 people, compared to Europe's 29.42 barrels of oil per day per 1,000 people. Of particular note is that several European countries are able to maintain GDP per capita at, near, or above US levels, with significantly lower energy consumption:

Table 9

\begin{tabular}{|l|c|c|}
\hline \multicolumn{1}{|c|}{ Country } & $\begin{array}{c}\text { GDP Per Capita } \\
\text { (US\$/year, 1998, per IMF, 2009) }\end{array}$ & $\begin{array}{c}\text { Energy Consumption } \\
\text { (BBL/day per 1000 people. Most } \\
\text { recent year for which data are } \\
\text { available, per CIA, 2008) }\end{array}$ \\
\hline United States of America & 45,790 & 68.7 \\
\hline Norway & 53,341 & 48.5 \\
\hline Switzerland & 42,783 & 32.4 \\
\hline Ireland & 42,539 & 48.9 \\
\hline Austria & 39,634 & 35.3 \\
\hline Denmark & 37,266 & 34.9 \\
\hline Sweden & 37,245 & 39.2 \\
\hline
\end{tabular}

Admittedly, Europe has some advantages over the USA, which enable Europeans to use less energy:

- $\quad$ Europe is more compact, with less distance between population centers.

- $\quad$ Europe has generally better rail and public transit systems.

- $\quad$ European homes are generally much smaller, requiring less energy to heat and cool.

- $\quad$ Because Europe is so much further north, European summers are cooler, requiring less air conditioning, but this is offset somewhat because European winters are generally cooler, requiring more energy to heat.

At the same time, these data suggest considerable potential for improvement. If the USA reduced its oil consumption to European levels, it would require no imports of oil from sources outside NAFTA. More realistically, a report prepared in 2005 for the Natural Resources Defense Council suggested that the United States could save an average of 2.5 million barrels per day by 2015 (Bordetsky, 2005). The proposed approach includes:

- $\quad$ Providing tax incentives to auto manufacturers to retool to build more energy-efficient vehicles

- $\quad$ Increasing the Corporate Adjusted Fuel Economy (CAFÉ) standards

- $\quad$ Requiring replacement tires and motor oil to be at least as fuel efficient as original equipment tires and motor oil;

- $\quad$ Requiring efficiency improvements in heavy-duty trucks;

- $\quad$ Supporting smart growth and better transportation choices.

- Expanding industrial efficiency programs to focus on oil use reduction and adopting standards for petroleum heating;

- $\quad$ Replacing chemical feedstocks with bioproducts through research and development and government procurement of bioproducts; 
- Upgrading air traffic management systems so aircraft follow the most-efficient routes; and

- $\quad$ Promoting residential energy savings with a focus on oil-heat.

Conservative commentator Charles Krauthammer has proposed a revenue-neutral consumption tax on gasoline to encourage conservation (Krauthammer, 2009). The principle behind this proposal is that a substantial tax be added to the price of motor fuel, with an offsetting reduction in the payroll tax. A driver who drove a lesser number of miles, or utilized a more fuel-efficient vehicle, than the standard would realize a net income from this approach. A variation of this approach is that revenue neutrality should apply to a majority of the tax, with the remainder comprising a net revenue stream that could be used to fund alternatives or research or infrastructure to reduce the use of oil. The savings resulting from the imposition of such a tax are not easily quantifiable, but reductions in consumption in response to the 2008 price spike would suggest that this could save at least 1 million barrels a day.

\section{Alternatives}

In the long run, the development of green energy technology will make the biggest difference in reducing or eliminating our dependence upon foreign, and even domestic, oil. The United States' energy policy needs a more forceful approach to making alternative energy sources mainstream (Toal, 2008). Oil is a natural resource and will deplete in time and as the problem of global warming becomes more severe, the need for alternative fuel becomes more and more imperative (Luchansky \& Monks, 2009). Unfortunately, in the short run all alternative fuels suffer from two basic shortcomings:

- $\quad$ Because the vast majority of oil is used for transportation, translating alternative energy into an alternative for oil is a difficult proposition.

- $\quad$ Alternatives compare poorly to traditional energy sources in at least one of the following areas:

- Scale

- Infrastructure

○ Price

The relevant question, as stated by Richard Heinberg, ultimately becomes, "To what degree can any given non-petroleum energy source, or combination of sources enable industrial civilization to survive the end of oil?" (Heinberg, 2006, p.138) Heinberg further notes that the advantages of oil as an energy commodity, and by implication the disadvantages of alternatives, are that oil is:

- $\quad$ Easily transported (liquid fuels are more easily transported than solids such as coal or gases such as methane, and may be carried in ships far more easily than can be gases);

- $\quad$ Energy-dense (gasoline contains roughly 40 kilowatt-hours per gallon);

- $\quad$ Capable of being refined into several fuels (including gasoline, kerosene, and diesel fuel) suitable for a variety of applications; and

- $\quad$ Suitable for a variety of uses (including transportation, heating, and the production of chemicals and other materials)

Because of the above limitations, the use of alternatives must be managed very carefully to obtain maximum advantage.

As noted above, Brazil gets $50 \%$ of its "gasoline" and over $40 \%$ of its motor fuels from Biofuels. An equivalent ratio here would mean somewhere between 5 and 6 million barrels per day from Biofuels. That level is clearly achievable, with relatively inexpensive modifications to automobiles to enable flex fuel operations. The US currently gets about 1 million barrels a day from corn ethanol, and further growth expectations for that market are limited. The quickest possibility of a material impact probably lies with sugarcane ethanol from Latin America. Estimates are that as much as $10 \%$ of world gasoline usage could be replaced with sugar cane ethanol using current technology (Goldemberg, 2007). Ron Soligo has estimated the potential for sugar cane ethanol from Latin America to be 2.5 to 3 million barrels per day, depending on amount of land dedicated and yields obtained (Soligo and Jaffe, 
2008). If the trade sanctions with Cuba were lifted, Juan Tomás Sanchez of the Association for the Study of the Cuban Economy estimates that Cuba alone could supply up to 3.2 billion gallons of ethanol annually (200,000 barrels/day, or $1 \%$ of total U.S. energy consumption), while Cuba expert Jorge Hernandez Fonseca projects a more modest production figure around 2 billion gallons per year (Elledge, 2009). The difficulty arises because the current sanctions make the acquisition of accurate information more difficult. Since Cuban sugar production has declined from 44 million tons/year in 1950 to 11 million tons/year today (Zuurbier, 2008), significant upside potential is obvious. These impacts are substantially larger than any other steps under consideration, except perhaps the "drill here, drill now" option. We would still be importing, but it would be from countries that are closer and have more in common than areas in the Middle East and elsewhere in the third world. The existence of a new cash crop in Latin America could dramatically improve their economies, reducing the pressure from illegal immigration, and could also provide farmers with an alternative to marijuana, cocaine, and other plants that are the source of many drugs currently being smuggled into the U.S. Moreover, the ability to use ethanol as a substitute for gasoline would introduce at least some elasticity into the gasoline consumption model, thereby limiting the exposure to oil price shocks in the future. The EPA estimates that use of sugar cane ethanol could reduce greenhouse gas (GHG) emissions by $61 \%$, compared to $21 \%$ for corn ethanol (EPA, 2011). Additional ethanol supplies could be obtained from domestic sugar cane and sugar beets. Estimating the potential production from these sources is difficult, but perhaps another 500,000 barrels per day would be possible. That would mean a total of 4 million barrels per day from ethanol, slightly less than the $40 \%$ number, but a significant reduction in oil consumption. Additionally, this would enable the installation of significant ethanol infrastructure now, to be in place already when more exotic forms of ethanol, like cellulosic, become commercially viable. Incurring those costs now would actually reduce the commercial viability threshold for the exotic sources of ethanol, as they become available.

The arguments against importing ethanol to add to domestic production center around the negative point that the US would still be importing. However, several counter-arguments should be kept in mind:

- $\quad$ The proposed approach makes full use of domestic ethanol production capability, so no domestic enterprise is harmed.

- Importing from Central America, the Caribbean, and South America places our energy supplies in far less jeopardy than importing from Asia and Africa.

- The development of an additional lucrative cash crop would aid Latin American economies; in addition to being a good neighbor, the US should also see some relief with its drug and immigration issues along its southern border.

- $\quad$ Ethanol would be the first true alternative to oil, and having it developed commercially in sufficient volumes would offer some elasticity to the oil-pricing problem, and provide some leverage against oil price spikes.

Perhaps the best-known alternative energy proposal is the approach advocated by Oklahoma oilman T. Boone Pickens, known as the "Pickens Plan." The essential elements of this plan (Pickens, 2009) are:

- $\quad$ Substantially increase the use of solar and wind power to produce electricity

- Use these solar and wind sources to replace electricity currently generated by natural gas, and convert the natural gas to liquefied natural gas (LNG) for use as automobile fuel, thus replacing imported oil

Current U.S. recoverable reserves of natural gas are estimated to be approximately 284 trillion cubic feet (DOE/EIA, 2011). Only Russia and Qatar are estimated to have larger natural gas reserves. Current U.S. production of natural gas is approximately 60 billion cubic feet per day (DOE/EIA, 2011, table 5.a), which is equivalent on an energy basis to about 10 million barrels of oil per day. This means that domestic natural gas reserves are equivalent to 13 years of demand at current levels. Of course, if the production of natural gas increases significantly to take the place of oil, then the reserve life gets shorter.

One problem with the Pickens Plan is that substantial and expensive infrastructure changes would be needed to support the use of LNG as motor fuel on a widespread basis. Like oil, natural gas is a finite resource, and as natural gas supplies run out these infrastructure changes would no longer have utility. Natural gas could be used as a fleet fuel (buses, taxis, corporate vehicle fleets) more easily, since the number of refueling positions can be 
reduced substantially. Natural gas also makes an excellent fuel source for generating electricity-it emits less pollution than any other fossil fuel, and it is well suited for the role of providing backup capacity to wind and solar generation (which are necessarily intermittent) because a gas turbine can be brought up to speed faster than most other generator prime movers. Also, expanded use of natural gas would require considerable development of additional domestic gas resources, so this would be an adjunct to, rather than an alternative to, the "drill here, drill now" approach.

A variation on the Pickens Plan would be to increase the use of natural gas to generate electricity, and to pair new natural gas generating plants with new solar/wind facilities. Gas turbines make an excellent complement to wind and solar, because gas turbines can be brought online in relatively short order on those occasions where the wind dies down or the sun disappears behind clouds. This would enable converting to electricity as a prime mover for more uses. Large trucks and buses currently use 2.5 million barrels a day (Rauber, 2011, p. 35). Transit systems could be converted to electricity, as could the railroad system, and rail could replace trucks for a significant amount of long-haul transportation. A significant portion of the remaining truck fleets could be converted to natural gas, particularly those trucks that make primarily local trips.

\section{Domestic Energy Production}

Much has been made of a Department of Energy/Energy Information Agency study, which suggested that additional domestic drilling, particularly offshore, would have what politicians have described as "little or no effect for ten years" (DOE/EIA, 2007). An in-depth reading of the report indicates that accelerated domestic drilling, particularly offshore, would be capable of producing and additional 1 million barrels a day within 5 to 7 years, and ultimately an additional 2 million barrels per day. The study was prepared in 2007 and it assumed that current prohibitions against offshore drilling would remain in effect until 2012, so that there would no activity for five years; because the start was thus delayed, the five years of activity required to get new wells on production became "ten years." The "little or no effect" comment was based on the assumption that 1 to 2 million barrels per day would represent on the order of 1 to 2 percent of worldwide consumption and thus would have little impact. In reality, 1 to 2 million barrels per day is a greater impact than any other proposed action, particularly within the 5-10 year time frame, except possibly sugarcane ethanol. Given the extremely inelastic nature of oil prices, and the role that speculation plays in setting oil prices, it is not inconceivable that a 1 to 2 percent shift in supply could have significant effects. As far as opposition to drilling on the grounds that it delays conversion to alternatives, we simply need to be pursuing two entirely independent tracks - we need to develop alternatives as quickly as possible, and we need to obtain as much conventional energy from domestic sources as possible until those alternatives come onstream in significant quantities.

Nuclear energy can be a huge part of the bridge to the future. Construction of 50-100 additional nuclear electric generating plants around the country would provide a stable firm electric generating capacity to support not only electric cars, but also the conversion of many heavy-duty applications to electricity - such as the conversion of the railroad system and mass transit systems. While the recent events following the Japanese earthquake and tsunami may cause some reevaluation of the future role of nuclear power, evaluation of the future role of nuclear must consider that any alternative involves some risk, and the most prudent strategy is to maximize the reward-torisk ratio.

The Japanese nuclear catastrophe, the BP/Deepwater Horizon/Macondo blowout in 2010, and any number of other disasters or near-disasters reinforce two messages - solving this problem will not occur without taking risks, and it will not be cheap. Those considerations would seem to make it an even stronger imperative to push forward on as many fronts as possible. Some will prove costlier or riskier than currently anticipated, while some will inevitably prove to be less so than anticipated. As these results manifest themselves, priorities can and should be shifted to increase emphasis on those approaches yielding happier results. Putting too many eggs in too few baskets increases the risk of being overly dependent upon a technology that ultimately proves too risky or too expensive. 


\section{Maximizing Use Of Existing Technology}

The importance of maximizing existing technology is apparent in the above discussion. Utilizing existing technology to the maximum extent possible means, for example:

- Instead of waiting on cellulosic ethanol to come out of the laboratory into mass production, we should accelerate the ethanol transition with sugar cane ethanol-produced both domestically and in Latin America, and

- $\quad$ Rather than waiting for the perfect solar technology to be developed we should start expanding solar power to the maximum extent possible with existing technology and upgrade to better technologies as they become available.

There are a number of areas where technological advances would be of significant help. The major ones probably include:

- Improved electric storage technology, particularly improved batteries. This has the potential to increase range of electric cars to 200 miles, at which point they become a viable alternative for many more people, and to allow energy from solar and wind to be stored more efficiently for use at peak load times.

- Coal gasification/liquefaction. These are existing processes, having been used extensively by Hitler's Germany to provide fuel for the Wehrmacht, but they currently create excessive amounts of $\mathrm{CO} 2$. Finding ways either to reduce the amount of $\mathrm{CO} 2$ created, or to make use of the $\mathrm{CO} 2$ or dispose of it in ways that do no harm, would greatly increase the utility of large existing domestic coal reserves.

- Nuclear waste disposal. One option, currently being done in France, is to reprocess spent fuel to extract useful fuel and reduce the radioactivity of the remaining residue waste product. Another option that shows some promise is to return spent fuel to the mine from whence it came.

These are probably the three potentially most rewarding research tracks. Solving the problems associated with any one of them would enable that alternative to take a more significant role going forward. Accordingly, they should be pursued as vigorously as possible, but that should not prevent taking advantage of technologies that have been developed.

\section{Emphasizing The Private Sector Role}

Allowing the private sector to participate on a cooperative, rather than adversarial, basis means that current oil and gas companies, and electric utilities, should transition to energy companies, and policies should be adopted to facilitate that transition and work cooperatively with those companies to reach solutions. Things that could be done would include:

- $\quad$ Adopting the Norwegian cooperative approach to planning offshore drilling and development, instead of the adversarial permitting process that has contributed to problems like the BP oil spill.

- $\quad$ Providing incentives for existing oil and gas companies to transition more into energy companies, including development of alternatives. These companies have the facilities needed for infrastructure requirements, the expertise in the industry, and the capital to make considerable impacts on the problem if properly encouraged to do so.

- $\quad$ Reducing or eliminating regulations, subsidies, and tariffs, which hamper the operation of the free market.

\section{SUMMARY AND CONCLUSIONS}

Returning to the table summarizing energy sources and uses presented earlier, the following is an estimate of what that table would look like in 2030-2035, with the changes outlined herein: 
Table 10

\begin{tabular}{|c|c|c|c|c|c|c|}
\hline \multirow{2}{*}{$\begin{array}{c}\text { (Amounts in quadrillions of } \\
\text { British Thermal Units } \\
\text { [BTU]) }\end{array}$} & \multirow{2}{*}{$\begin{array}{c}\text { Produced or } \\
\text { purchased }\end{array}$} & \multicolumn{5}{|c|}{ Used For } \\
\hline & & Transport & Industrial & Commercial & Residential & Electricity \\
\hline \multicolumn{7}{|l|}{ Oil } \\
\hline -Domestic & 20.0 & & & & & \\
\hline -Imported & 7.0 & & & & & \\
\hline Total & 27.0 & 18.0 & 6.0 & 1.0 & 1.0 & 1.0 \\
\hline Natural gas & 33.0 & 5.0 & 10.0 & 4.0 & 4.0 & 10.0 \\
\hline Coal & 15.0 & & 2.0 & & & 13.0 \\
\hline Renewables/Biofuels & 15.0 & 1.0 & 3.0 & 1.0 & 3.0 & 7.0 \\
\hline Nuclear & 15.0 & & & & & 15.0 \\
\hline Subtotals & 105.0 & 24.0 & 21.0 & 6.0 & 8.0 & 46.0 \\
\hline Use of electricity & & 7.0 & 12.0 & 13.0 & 14.0 & $(46.0)$ \\
\hline Totals & 105.0 & 31.0 & 33.0 & 19.0 & 22.0 & - \\
\hline
\end{tabular}

At this level, the US could meet its imported oil requirements from its NAFTA neighbors, Canada and Mexico, if they maintained their current levels of production. Note that coal consumption has decreased considerably; development of reasonable processes for coal liquefaction/gasification, listed above as a major research initiative, would potentially increase coal production and replace some of the oil and/or natural gas in the above table.

The 12 million barrels of oil that the USA currently imports every day create significant national security, environmental, and economic problems. There is no approach that will replace those imports, or the 20 million barrels of oil that the US uses every day. There simply is no good substitute for oil. However, the example of Brazil suggests that there may be a way to break down into smaller pieces and use multiple approaches, one to address each piece. Brazil has eliminated its dependence on foreign oil, and in fact become a major exporter of oil, by following a strategy of using all possible alternatives, emphasizing currently available technology that was "good enough" instead of waiting for the "perfect" answer to come out of the laboratory, and relying on the private sector to execute the solutions. This two primary activities resulting from this approach were a Biofuels program that currently accounts for about $44 \%$ of Brazil's on-the-road fuel, and a "drill here, drill now" effort that provides the other $56 \%$ plus exports. If the USA follows a similar approach and divides its problem into three parts, it may be possible to get more than 3 million barrels each from conservation, from alternatives, and from increased domestic production of conventional energy. Pessimistically, it has been suggested that the USA has about 50 years before the price and availability of oil will make the present level of reliance on oil unfeasible. Optimistically, alternatives will become viable on a large scale in about 35 years. That leaves a very small window of opportunity. The USA needs to start moving much faster, and with much better focus, to achieve a viable solution to its energy situation. In the end, Paris Hilton is right-use domestic sources aggressively but responsibly to minimize pain in the short run, while pursuing alternatives with at least equal fervor in order to make the transition which must take place in the next 50 years as smooth and seamless as possible.

\section{AUTHOR INFORMATION}

Robert B. Matthews, J/D/, C.P.A., M. Acctg., is assistant professor of business administration at Sam Houston State University. He received an undergraduate degree in mathematics and economics, and a master's degree in accounting, from Rice University, and a law degree from the University of Houston Law Center. Prior to joining the faculty at SHSU, he spent 35 years as a financial and legal consultant to numerous clients, primarily in the energy industry. Email: rbm003@shsu.edu

Eric Steglich received his M.B.A. from Sam Houston State University. This paper is derived from, and an expansion of, a paper he prepared while a graduate student at SHSU. Email: easteglich@aol.com 


\section{REFERENCES}

1. American Council for an Energy-Efficient Economy (1999), Policies for a More Sustainable Energy Future.

2. Baird, S. (2008), “Offshore oil drilling: Buying energy independence or buying time?” The Technology Teacher (November), pp.13-17.

3. Bordetsky, A., R. Hwang, A. Korin, D. Lovaas, and L. Tonachel (2005), Securing America: Solving our Oil Dependence through Innovation, Natural Resources Defense Council, 2005.

4. Cato Institute (2008), Cato Handbook for Policymakers, Washington, DC, USA: Cato Institute.

5. Cleveland, C. J., R. Costanza, C. A. S. Hall, and R. Kaufmann (1984), "Energy and the U.S. Economy: A Biophysical Perspective," Science, vol. 225, pp. 890-897.

6. Cochet, Yves (2002), interview with BBC (February), from the author's personal recollection, transcript unavailable.

7. Dodge, J. (2008), "First comes hydrogen cars. The refueling infrastructure will follow." Design News, October 2008, pp. 55-56.

8. Elledge, Nicholas (2009), "Cuba’s Sugarcane Ethanol Potential: Cuba, Raul Castro, and the Return of King Sugar to the Island," Council on Hemispheric Affairs.

9. Gingrich, Newt (2006), Winning the Future: A 21 ${ }^{\text {st }}$ Century Contract with America, Washington, DC, USA: Regnery Publishing, Inc.

10. Gingrich, Newt (2008), Real Change: From the World that Fails to the World that Works, Washington, DC, USA: Regnery Publishing, Inc.

11. Goettemoeller, Jeffrey, and Adrian Goettemoeller (2007), Sustainable Ethanol: Biofuels, Biorefineries, Cellulosic Biomass, Flex-Fuel Vehicles, and Sustainable Farming for Energy Independence, Maryville, MO, USA: Prairie Oak Publishing.

12. Goldemberg, Jose (2007), "The Potential for $1^{\text {st }}$ Generation Ethanol Production from Sugarcane," Sao Paulo, Brazil: University of Sao Paulo.

13. Greene, D.L., D. W. Jones, and P. N. Leiby (1998), “The Outlook for U.S. Oil Dependence,” Energy Policy, vol. 26, no. 1, pp. 55-69.

14. Edwards, P., V. Kuznetsov, W. David, and N. Brandon (2008), "Hydrogen and fuel cells: Towards A Sustainable Energy Future," Energy Policy, vol. 36, pp. 4356-4362.

15. Feltus, A. (2006), "Tapping the Spine of America," Petroleum Economist, 2006, vol. 73 no. 3, p. 25.

16. Heinberg, Richard (2006), The Party's Over: Oil, War, and the Fate of the Industrial States, Gabriola Island, BC, Canada: New Society Publishers.

17. International Monetary Fund (2009), "World Economic Outlook Database-April 2009," online at http://www.imf.org/external/pubs/ft/weo/2008/01/weodata/index.aspx. Accessed on April 22, 2009.

18. Kotchen, M.J. \& N. E. Burger (2007), "Should We Drill in the Arctic National Wildlife Refuge? An Economic Perspective," Energy Policy, vol. 35, no. 9, pp. 4720-29.

19. Krauthammer, Charles (2009), "The Net-Zero Gas Tax: A Once-in-a-Generation Chance," The Weekly Standard, vol. 14, no. 16 (January 5).

20. Luchansky, M. \& J. Monks (2009), "Supply and Demand Elasticities in the U.S. Ethanol Fuel Market," Energy Economics, vol. 31, pp. 403-410.

21. Misbach, Eric (2009), “A Blueprint for a Clean Energy Economy,” Catalyst (Summer), Union of Concerned Scientists, pp. 7-10.

22. Mouawad, J. (2006), "Drilling Deep in the Gulf of Mexico," The New York Times, (November 8). Retrieved March 1, 2009, from http://www.nytimes.com/2006/11/08/business/worldbuiness/08gulf.html? r=1\&pagewanted=print.

23. Murugesan, A., N. Nedunchezhian, R. Subramanian, and C. Umarani (2009), "Bio-diesel as an Alternative Fuel for Diesel Engines-A Review," Renewable and Sustainable Energy Reviews, vol. 13 no. 3, pp. 653662.

24. National Renewable Energy Laboratory (2008), "Ethanol basics," (October), online at http://afdc.energy.gov/afdc/pdfs/43835.pdf.

25. Obama, Barack (8/28/2008), "The American Promise," acceptance speech at Democratic National Convention, Denver, CO, USA.

26. Obama, Barack (1/25/2011), State of the Union speech, Washington, DC, USA. 
27. Obama, Barack (3/11/2001), press conference, Washington, DC, USA.

28. Odum, Howard T. (1976), Environmental Accounting, Energy, and Decision Making, New York, NY, USA: John Wiley.

29. Pickens, T. Boone (2009), "The Pickens Plan”, online at http://www.pickensplan.com/theplan/.

30. Pimental, D., A. Pleasant, J. Barron, J. Gaudioso, N. Pollock, E. Chae, Y. Kim, A. Lasiter, C. Schaivoni, A. Jackson, M. Lee, and A. Eaton (2002), "U.S. Energy Conservation and Efficiency: Benefits and Costs," Ithaca, NY, USA: College of Agriculture and Life Sciences, Cornell University, (April 26).

31. Rauber, Paul (2011), "Beyond Oil in 20 Years," Sierra, Sierra Club (January/February), vol. 96, no. 1, pp. 32-36.

32. Reel, Monte (2006), "Brazil's road to energy independence," The Washington Post (August 20)

33. Sandalow, David (2007), "Ending Oil Dependence. Protecting National Security, the Environment, and the Economy", Washington, DC, USA: Brookings Institute, online at http://www.brookings.edu/papers/2007/0228globalenvironment_sandalow_Opp08.aspx

34. Sandalow, David (2008), Freedom from Oil: How the next President Can End the United States' Oil Addiction, New York, NY, USA: McGraw-Hill.

35. Schmidt, C. (2007), "Biodiesel: Cultivating Alternative Fuels," Environmental Health Perspectives, vol.115, no. 2, pp. A86-A91.

36. Schwind, Scott (coordinator), Sergio Baron, Andy Duff, Sergio Andre Laclau, and Girard Miller (2007), Biodiesel and Ethanol Projects in Latin America: A Case Study on the Brazilian Experience, Houston, TX, USA: Fulbright \& Jaworski, LLP, (presented June 26).

37. Siegel, Jeff (2008), "Cuban Sugar Cane Ethanol," Energy and Capital, (February), online at: http://www.energyandcapital.com/articles/cuba-sugar+cane-ethanol/625.

38. $\quad$ Smith, E. (2007), "Rocky Mountain Oil.” Retrieved March 9, 2009, from: http://www.nuwireinvestor.com/articles/rocky-mountain-oil-51062.aspx

39. Soligo, Ronald (7/23/2008), "Ethanol and Energy Policy," presentation to James A. Baker III Institute of Public Policy, Rice University, Houston, TX, USA.

40. Soligo, Ronald, and Amy Myers Jaffe (8/20/2008), "The Impact of Biofuels on Western Hemisphere Energy Security," presentation to James A. Baker III Institute of Public Policy, Rice University, Houston, TX, USA.

41. Sovacool, B. (2007), "Solving the Oil Independence Problem: Is it Possible?" Energy Policy, vol. 35, pp. 5505-5514.

42. Toal, B. (2008), "Think Outside the Barrel," Oil \& Gas Investor, p. 6, retrieved April 11, 2009, from Business Source Complete database.

43. U.S. Central Intelligence Agency (2008), "Energy Statistics > Oil > Consumption (per capita) (most recent) by Country", derived from World Factbooks, December 2003-December 2008, online at http://www.nationmaster.com/graph/ene_oil_con_percap-energy-oil-consumption-per-capita.

44. U.S. Department of Energy, Energy Information Administration (2007), "Impacts of Increased Access to Oil and Natural Gas Resources in the Lower 48 Federal Outer Continental Shelf," Washington, DC, USA: U.S. Government Printing Office.

45. U.S. Department of Energy, Energy Information Administration (2009), "Crude Oil and Petroleum Imports: Top 15 Countries," (March), online at http://www.aia.doe.gov/pub/oil_gas/petroleum/data_publications/company_level_imports/current/import.ht $\underline{\mathrm{ml}}$.

46. U.S. Department of Energy, Energy Information Administration (2009), "Weekly Retail Gasoline and Diesel Prices," (March), online at http://tonto.eia.doe.gov/dnav/pet/pet_pri_gnd dcus_nus_w.htm.

47. U.S. Department of Energy, Energy Information Administration (2009), "Annual Energy Outlook," Washington, DC, USA: U.S. Government Printing Office.

48. U.S. Department of Energy/Energy Information Administration (2011), "Brazil Country Analysis Brief," retrieved from http://www.eia.doe.gov/emeu/cabs/Background.html.

49. U.S. Department of Energy, Energy Information Administration (2011), "Crude Oil and Total Petroleum Imports: Top 15 Countries," retrieved February 27, 2011, from http://www.eia.doe.gov/pub/oil_gas/petroleum/data_publications/company_level_imports/current/import.ht $\underline{\mathrm{ml}}$. 
50. U. S. Environmental Protection Agency (2002), “Clean Alternative Fuels,” (March), online at http://www.epa.gov/otaq/consumer/fuels/altfuels/420f00034.pdf.

51. U.S. Department of Energy, Energy Information Administration (2011), "Short Term Energy Outlook," online at http://www.eia.doe.gov/emeu/steo/pub/contents.html.

52. U.S. Environmental Protection Agency (2010), "Renewable Fuel Standard Program (RFS2) Regulatory Impact Analysis," retrieved February 11, 2011, from http://www.epa.gov/otaq/renewablefuels/420r10006.pdf.

53. Zuurbier, Peter, and Jos van de Vooren (2008), Sugar Cane Ethanol, Wageningen, Netherlands: Wageningen Academic Publishers. 
NOTES 